\title{
Patient charters: the provincial experience
}

Published at www.cmaj.ca on Aug. 17

$\mathrm{S}$ cratch the surface of recent health care reform and you'll likely find a commitment to "patient-centred care." In some nations, the concept is even viewed as integral to a retooling of health care systems.

But beyond a general promise to put patients at the heart of health care decision-making, most nations are still in the early stages of defining concrete parameters for the delivery of patientcentred care.

At the front of the trend, countries such as Australia and the United Kingdom have enshrined the rights of patients in national charters, which outline what consumers can reasonably expect in terms of health care standards and accessibility. In some nations, charters have the force of law; in others, they are statements of health policy. Across the board, however, they serve the same function: to empower patients and serve as guidelines for the delivery of health care services.

And patient charters or bills of rights are far from novel in Canada, says Karen Philp, chair of the Canadian Patient Summit.

There have been repeated attempts to acknowledge patient rights at the provincial level, while discussions surrounding the creation of a national patient charter have been fueled by a recent Canadian Medical Association proposal to establish such a creature (www.cma.ca/multimedia/CMA/Content _Images/Inside_cma/Advocacy/HCT /HCT-2010report_en.pdf).

"Patient charters have been floating around since the 1990s, but just haven't been seriously implemented. Canada's on the verge of the cutting edge in that respect," says Philp.

The provinces have taken a range of approaches to establishing patient charters: the Ontario and Alberta legislatures have introduced private members' bills to enact codes of patient rights and responsibilities, Quebec has legislated

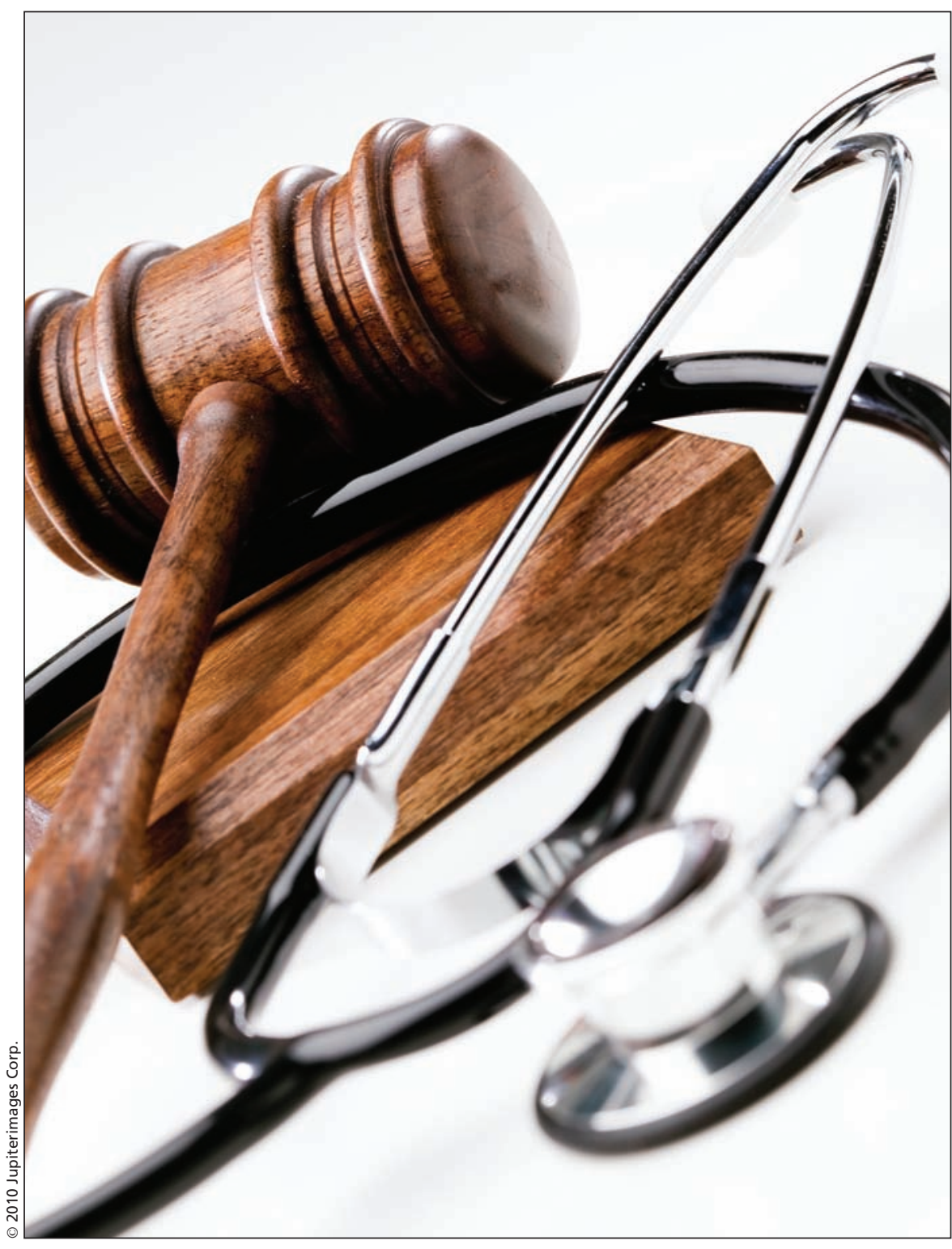

Concerns that legislating patient rights might lead to legal actions against a province and otherwise be too costly to enforce have been the major obstacle to enshrining patient rights in law, says the cochair of a national advocacy group.

certain patient entitlements, and other provinces have set goals, objectives and expectations for patient-centred care in planning and policy documents (dsp-psd .pwgsc.gc.ca/Collection-R/LoPBdP/BP /prb0131-e.htm).

Thus far, the legislative approach has been the least effective.

In the late-1990s, three private mem- bers' bills to promote patient rights were introduced in the Ontario legislature over a three-year span. The most recent of these - Bill 18, Health Care Accountability and the Patients' Bill of Rights Act, 1999 — set out both collective and individual rights for Ontario patients, including the right to a universal, accessible health care system, 
timely treatment, freedom of choice, participation in the development of plans for care, mechanisms for filing complaints, and individual dignity, privacy and autonomy (www.ontla.on.ca /bills/bills-files/36_Parliament/Session3 /b018.pdf). None of the three bills were passed into law.

Around the same time, Bill 201, an Alberta Patients' Bill of Rights was introduced (www.assembly.ab.ca /ISYS/LADDAR_files/docs/bills/bill /legislature_24/session_2/19980127_bill -201.pdf LINK). The bill would have provided patients with various rights, including the right to receive health care without discrimination, refuse consent to any proposed treatment, and have access to their health information unless, in the opinion of a relevant health professional, the disclosure could result in immediate harm to their health and safety. That bill was quickly defeated.

Where rights have been more limited in scope, legislation has been more successful.

Quebec's Act Respecting Health Services and Social Services, 1991, sets out the patient's entitlement to be informed of health and social services resources and receive the care required when their life or bodily integrity is endangered, receive health services in a continuous and personalized manner, choose the professional or institution to deliver those services, and participate in decisions affecting their care (www2.publicationsduquebec.gouv.qc. ca/dynamicSearch/telecharge.php?type $=2 \& f i l e=/ S \_4 \_2 / S 4 \_2 \_A . h t m l$ ).

The act also sets out a mechanism for complaint. However, it limits the application of those entitlements by including an availability and feasibility clause. For example, entitlements to health services and a choice of health care provider only apply within the context of an institution's available human and financial resources.

More recently, Ontario's Long Term Care Homes Act, 2007, included a bill of rights for residents of long-term care homes. The legislation enshrines such residents' rights as: receiving proper care; knowing who is looking after them; keeping personal belongings in their room; understanding their treatment; giving or refusing consent to treatment; obtaining a second opinion on any aspect of their care; and sharing a room with their spouse (www.e-laws.gov.on .ca/html/statutes/english/elaws_statutes _07108_e.htm).

Concerns that legislating patient rights might lead to legal actions against a province and otherwise be too costly to enforce have been the major obstacle to enshrining patient rights in law, says Kathy Kovacs-Burns, cochair of the Best Medicines Coalition, a national alliance of advocacy groups that represents people living with chronic diseases. "Charters are valuebased documents, so they really pose a challenge for governments to legislate and monitor."

Some provinces have sidestepped those pitfalls by including patient rights in policy documents and guidelines.

When Nova Scotia's provincial health council concluded that a legislated patients' rights document would "pose innumerable legal problems that might take years to resolve through the courts," they opted to release a nonbinding set of expectations instead. While those cover the same ground as a bill of rights - dealing with issues of access to resources, dignity, and safety — they only act as voluntary guidelines for the delivery of care.

The efficacy of such measures is questionable, says Dr. Jane Brooks, pres- ident of Doctors Nova Scotia. "It's really just a document, and people can refer to it if they want to, but it's not something that's at the forefront of patients' minds."

Many hospitals, clinics and medical associations have established guidelines or voluntary charters for patientcentred care.

Despite the checkerboard experience and legal concerns, the push for legislated provincial charters is far from over.

The final report of Saskatchewan's Patient First Review, For Patients' Sake (2009), devoted considerable attention to the need to reorient health care to a more patient-centred system (www.health.gov .sk.ca/patient-first-commissioners-report). The report recommended the adoption of a charter of patient rights and responsibilities.

More recently, an advisory committee to the Alberta Minister of Health also recommended the creation of a provincial patient charter (www.health.alberta.ca /documents/MACH-Final-Report-2010 -01-20.pdf).

The Canadian Medical Association will discuss the possibility of a national charter at its upcoming annual general meeting in Niagara Falls, Ontario. Lauren Vogel, CMAJ

DOI:10.1503/cmaj.109-3339

First of a three-part series

Part II: Patient charters all buzz and no bite, advocates say (www.cmaj.ca/cgi/doi/10.1503/cmaj.10 9-3340)

Part III: Patient charters: the international experience (www.cmaj.ca/cgi/doi/10.1503/cmaj.10 9-3342) 